Yusrina, et al/Jurnal Ekonomi Syariah Teori dan Terapan Vol. 6 No. 12 Desember 2019: 2512-2526;

ANALISIS PERBEDAAAN AVERAGE ABNORMAL RETURN DAN TRADING VOLUME ACTIVITY SEBELUM DAN SESUDAH PERISTIWA DIVIDEN TUNAI PADA PERUSAHAAN YANG TERDAFTAR DI JAKARTA ISLAMIC INDEX (JII) PERIODE 2014 - 2017

\title{
ANALISIS PERBEDAAAN AVERAGE ABNORMAL RETURN DAN TRADING VOLUME ACTIVITY SEBELUM DAN SESUDAH PERISTIWA DIVIDEN TUNAI PADA PERUSAHAAN YANG TERDAFTAR DI JAKARTA ISLAMIC INDEX (JII) PERIODE 2014 - 20171
}

\author{
Azyyati Yusrina \\ Departemen Ekonomi Syariah - Fakultas Ekonomi dan Bisnis - Universitas Airlangga \\ Email: azyyati.yusrina-2014@feb.unair.ac.id \\ Puji Sucia Sukmaningrum \\ Departemen Ekonomi Syariah - Fakultas Ekonomi dan Bisnis - Universitas Airlangga \\ Email: puji.sucia@feb.unair.ac.id
}

\begin{abstract}
:
This study aims to find out and explain the market reaction caused by the corporate action announcement in the form of dividend cash made by issuers registered in the Jakarta Islamic Index for the period of 2014 to 2017. The object of research is issuers who carry out activities on the announcement of Cash Devidend in the period of observation that are registered in the Jakarta Islamist Index which has been determined based on certain criteria (purposive sampling). There are 17 issuers with a total of 91 being the research sample. The observation period consists of 60 days estimated period, 10 days before the cume date and 10 days after the cume date. The focus of the research is to see the reaction shown by changes in Average Abnormal Return and Trading Volume Activity by using paired sample $t$ test for trading volume activity variables and Wilcoxon sign-rank test for abnormal return variables. Processing data using Stata ver statistical tools 14 by setting a significant level of 5\%. The results showed that there were significant differences in Average Abnormal Return before and after the announcement and there were no differences in the Trading Volume Activity before and after the announcement.
\end{abstract}

Keywords: event study, cash deviden, Average Abnormal Return, Trading Volume Activity

\section{PENDAHULUAN}

Perkembangan dunia ekonomi yang terus berkembang, mengakibatkan perubahan ketertarikan dari pelaku ekonomi yaitu salah satunya terhadap peran pasar modal sebagai sarana transaksi ekonomi dan sarana penghimpun dana dari pelaku bisnis maupun masyarakat.

Keberadaan pasar modal diharapkan mampu mendorong aktivitas perekonomian Indonesia kearah yang lebih baik karena banyak perusahaan yang menggantungkan kegiatanya di pasar modal sebagai alternatif pendanaan jangka panjang bagi perusahaan, sehingga perusahaan dapat melakkan ekspansi dan meningkatkan laba perusahaan.

Pasar modal membuat alokasi dana menjadi lebih efisien. Pertemuan pihak yang memiliki kelebihan dana dengan pihak yang membutuhkan dana melalui transaksi sekuritas terjadi di pasar modal (Tandelilin, 2010:26). Pihak yang kekurangan dana atau invstor dapat memilih alternatif investasi yang memberikan return yang optimal dengan

\footnotetext{
${ }^{1}$ Jurnal ini merupakan bagian dari skripsi dari Azyyati Yusrina, NIM: 041411431089 , yang diuji pada 17 Juli 2019.
} 
Yusrina, et al/Jurnal Ekonomi Syariah Teori dan Terapan Vol. 6 No. 12 Desember 2019: 2512-2526;

ANALISIS PERBEDAAAN AVERAGE ABNORMAL RETURN DAN TRADING VOLUME ACTIVITY SEBELUM DAN SESUDAH PERISTIWA DIVIDEN TUNAI PADA PERUSAHAAN YANG TERDAFTAR DI JAKARTA ISLAMIC INDEX (JII) PERIODE 2014 - 2017

memilih perusahaan yang paling produktif di pasar modal, sedangkan pihak yang membutuhkan dana atau perusahaan perusahaan yang terpilih oleh investor untuk menerima tambahan modal tersebut dapat memanfaatkan tambahan modal untuk membiayai kegiatan operasional perusahaan sehingga laba bisa lebih meningkat. Peningkatan laba tersebut akan meningkatkan return yang diberikan perusahaan kepada investor, sehingga kesejahteraan prusahaan dan investor dapat tercapai.

$$
\text { Studi peristiwa (event study) }
$$
merupakan studi yang mempelajari reaksi pasar terhadap suatu peristiwayang informasinya dipublikasikan sebagai suatu peristiwa (Jogiyanto, 2015: 623). Apabila pengumuman mengandung informasi (information content), maka diharapkan akan terjadi reaksi oleh pasar pada saat pengumuman tersebut diterima oleh pasar.

Kebijakan dividen merupakan keputusan untuk menentukan besarnya bagian pendapatan yang akan dibagikan kepada para pemegang saham dan bagian yang akan ditahan di perusahaan. Dividen merupakan sebagian atau seluruh laba perusahaan dalam menjalankan bisnis yang dibagikan kepada pemegang saham (Tandelilin, 2010:32). Terdapat dua jenis pembagian dividen berdasarkan bentuk dividen yang dibayarkan yaitu dividen tunai (cash dividend) dan dividen saham (stock dividend). Dividen tunai (cash dividend) adalah dividen yang dibayarkan dalam bentuk tunai

Menurut Suad Husnan (2001), teori kebijakan dividen yang optimal diartikan sebagai rasio pembayaran dividen yang ditetapkan dengan memperhatikan kesempatan untuk menginvestasikan dana serta sebagai preferensi yang dimiliki para pemegang saham mengenai dividen daripada capital gain. Kebijakan dividen tersebut juga dipandang untuk menciptakan keseimbangan antara saat ini dengan pertumbuhan di masa yang akan datang sehingga dapat memaksimumkan harga saham (Brigham, 2001).

Berkembangnya ekonomi Islam terutama di Indonesia menjadi salah satu faktor utama dalam meningkatkan kesadaran masyarakat muslim untuk dapat bertransaksi dipasar modal yang sesuai dengan prinsip syariah, hal tersebut dibuktikan dengan adanya produkproduk syariah seperti indeks saham syariah dipasar modal seperti Jakarta Islamic Indeks (JII). Indeks JII adalah salah satu indeks saham yang ada pada Bursa Efek Indonesia yang menghitung indeks rata-rata 30 saham yang memenuhi kriteria syariah.

Dari pengumuman dividen ini investor dapat memperkirakan bagaimana kondisi perusahaan di masa depan yang dapat dilihat dari harga saham perusahaan. Investor juga dapat memutuskan dimana mereka akan melakukan investasi atau memutuskan 
Yusrina, et al/Jurnal Ekonomi Syariah Teori dan Terapan Vol. 6 No. 12 Desember 2019: 2512-2526;

ANALISIS PERBEDAAAN AVERAGE ABNORMAL RETURN DAN TRADING VOLUME ACTIVITY SEBELUM DAN SESUDAH PERISTIWA DIVIDEN TUNAI PADA PERUSAHAAN YANG TERDAFTAR DI JAKARTA ISLAMIC INDEX (JII) PERIODE 2014 - 2017

mereka harus menjual atau tidak sahamnya.

\section{LANDASAN TEORI DAN PENGEMBANGAN HIPOTESIS}

Berdasarkan kaidah fikih, menurut asas-asas hukum muamalah yang dijelaskan oleh Basyir (2004:15), hukum asal dari kegiatan muamalah adalah mubah (boleh), selama tidak bertentangan dengan Al-Quran dan Hadits. Adanya peraturan dalam muamalah hakikatnya adalah bertujuan untuk mendatangkan kemashlahatan untuk kita dan menghilangkan segala ke mudhorotan. Seperti halnya Allah mengharamkan RIBA karena terdapat banyak kemudhoratan didalamnya.

Investasi merupakan penempatan dana pada berbagai aktiva keuangan sebagai upaya untuk meningkatkan modal atau kekayaan, baik melalui investasi pada real asset maupun investasi melalui financial asset dengan tujuan untuk memperoleh pendapatan optimal dengan risiko minimal di masa yang akan datang. Menurut Sunariyah investasi dalam arti luas terdiri dari dua bagian utama, yaitu investasi pada sektor rill dan investasi pada pasar vang atau surat berharga.

Islam mengajarkan umatnya untuk berusaha mendapatkan kehidupan yang lebih baik di dunia maupun di akhirat. Maka dari itu investasi dalam Islam merupakan kegiatan yang sangat di anjurkan untuk mencapai kesejahteraan sesama muslim. Akan tetapi Tidak semua jenis investasi diperbolahkan dalam Islam. investasi yang sesuai dalam ajaran Islam yang boleh diikuti oleh investor muslim. Prinsip-prinsip tersebut meliputi jenis usaha dan transaksi yang harus mengikuti norma-norma syariah Islam.

Saham sebagai salah satu alternatif media investasi memiliki potensi tingkat keuntungan dan kerugian yang lebih besar dibandingkan media investasi lainnya dalam jangka panjang. Saham adalah surat berharga sebagai tanda kepemilikan seseorang atau badan terhadap suatu perusahaan, sehingga pemegang saham memiliki hak klaim atas dividenatau distribusi lain yang dilakukan perusahaan kepada pemegang sahamnya, termasuk hak klaim atas aset perusahaan, dengan prioritas setelah hak klaim pemegang surat berharga lain dipenuhi jika terjadi likuiditas.

Return saham adalah tingkat keuntungan yang dinikmati oleh pemodal atas suatu investasi yang dilakukannya. Pasar saham tidak menjanjikan suatu return yang pasti bagi para investor. Namun berharap komponen return pada saham yang memungkinkan investor meraih keuntungan adalah dividen dan capital gain (Darmadji dan Fakhruddin, 2011:9).

Market Model, Pada prinsipnya model ini menggunakan bentuk dari single index model dengan batasan yang lebih sedikit. Model ini hampir samadengan single index hanya pada single index menggunakan kesalahanresidu saham 
Yusrina, et al/Jurnal Ekonomi Syariah Teori dan Terapan Vol. 6 No. 12 Desember 2019: 2512-2526;

ANALISIS PERBEDAAAN AVERAGE ABNORMAL RETURN DAN TRADING VOLUME ACTIVITY SEBELUM DAN SESUDAH PERISTIWA DIVIDEN TUNAI PADA PERUSAHAAN YANG TERDAFTAR DI JAKARTA ISLAMIC INDEX (JII) PERIODE 2014 - 2017

tidak mempunyai kovarians yang sama, sedangkan padamodel ini tidak digunakan.

$E(R i t)=a i+\beta i E(R m t)$

Keterangan :

$E($ Rit $)=$ Expected return i pada periode ke $\dagger$

$E(R m t)=$ Expected market return pada periode estimasi $\dagger$

ai $=$ Konstanta, variabel acak yang independen terhadap pasar

$\mathrm{Bi}=$ Beta pasar

Bentuk efisiensi pasar dapat ditinjau tidak hanya dari ketersediaan informasi, tetapi juga dilihat dari kecanggihan pelaku pasar dalam pengambilan keputusan berdasarkan analisis dari informasi yang tersedia. Secara formal pasar modal yang efisien dapat didefinisikan sebagai pasar yang harga sekuritasnya telah mencerminkan semua informasi yang relevan (Martalena, 2011:41).

Secara umum efisiensi pasar (Market efficiency) didefinisikan oleh Beaver (1989) sebagai hubungan antara harga-harga sekuritas dengan informasi. Didalam konsep pasar efisien, perubahan harga suatu sekuritas saham di waktu yang lalu tidak dapat digunakan dalam memperkirakan perubahan harga di masa yang akan datang.

Reaksi pasar merupakan respon pasar terhadap suatu peristiwa yang mengandung informasi ekonomisyang bernilai bagi investor. Pengujian respon oleh pasar terkait dengan hipotesis efisiensi informasi ( kecepatan respon pasar) dan hipotesis efisiensi keputusan (ketetapan respon pasar) (Tandellin, 2010:571).

Menurut Husnan (1996: 111-112), Volume Aktivitas Perdagangan saham dapat digunakan untuk melihat apakah investor secara individu menilai suatu peristiwa sebagai suatu yang informatif, dalam arti, apakah informasi tersebut akan membuat keputusan investasi yang berbeda dari keputusan investasi normal.

Menurut Husnan

(2009:269):

"Abnormal return adalah selisih antara tingkat keuntungan sebenarnya dengan tingkat keuntungan yang diharapkan." Sedangkan Menurut Jogiyanto (2010:416): "Return tidak normal (abnormal return) adalah selisih antara return sesungguhnya yang terjadi dengan return ekspektasi"

Menurut Jogiyanto (2010:94-96) Return tak normal adalah selisih antara return sesungguhnya yang terjadi dengan return ekspektasian yangdapat dihitung melalui rumus :

$R T N i, \dagger=R i, \dagger-E(R i, t)$

Keterangan :

RTNi, $t^{\prime}=$ return taknormal (abnormal return) sekuritas ke-i pada perioda peristiwa ke-t.

$\mathrm{Ri}, \dagger=$ return sesungguhnya yang terjadi untuk sekuritas ke-i pada perioda peristiwa ke-t.

$\mathrm{E}[\mathrm{Ri}, \mathrm{t}]=$ return ekspektasian sekuritas ke-i untuk perioda peristiwa ke-t. 
Yusrina, et al/Jurnal Ekonomi Syariah Teori dan Terapan Vol. 6 No. 12 Desember 2019: 2512-2526;

ANALISIS PERBEDAAAN AVERAGE ABNORMAL RETURN DAN TRADING VOLUME ACTIVITY SEBELUM DAN SESUDAH PERISTIWA DIVIDEN TUNAI PADA PERUSAHAAN YANG TERDAFTAR DI JAKARTA ISLAMIC INDEX (JII) PERIODE 2014 - 2017

RRTNt $=\frac{1}{N} \sum_{i-1}^{n} \mathrm{RTN} i, t$

Keterangan :

RRTNt = rerata return taknormal laverage abnormal return) pada hari ke- $\dagger$ $\mathrm{RTNi}, \mathrm{t}=$ return taknormal (abnormal return) untuk sekuritas ke-i pada hari ke- $\dagger$

$\mathrm{N}=$ jumlah sekuritas yang terpengaruh oleh pengumuman peristiwa

Trading Volume Activity (TVA) atau

Volume Aktivitas Perdagangan saham adalah perbandingan saham yang diperdagangkan pada waktu tertentudengan jumlah saham yang beredar di pasar.Pendekatan trading volume activity ini dapat digunakan untuk menguji hipotesis pasar efisien bentuk lemah (weak form efficiency) karena pada pasar yang belum efisien atau efisien dalam bentuk lemah, perubahan harga belum dengan segera mencerminkan informasi yang ada sehingga peneliti hanya dapat mengamati reaksi pasar modal melalui pergerakan volume perdagangan pada pasar modal yang diteliti (Sunur, 2006).

Kegiatan perdagangan saham diukur dengan menggunakan indikator sebagai berikut :

TVAit

$=\frac{\sum \text { saham yang di perdagangkan pada waktu } \mathrm{t}}{\sum \text { saham yang beredar di BEI pada waktu } \mathrm{t}}$

Aktivitas perusahaan melalui corporate action pada umumnya sangat di perhatikan oleh para pemegang saham ataupun pihak-pihak yang terkait di pasar modal. Corporate action merupakan kebijakan yang diambil perusahaan yang bertujuan menunjukan kinerja ataupun perbaikan kinerja untuk jangka pendek maupun jangka panjang (Fakhrudin dan Darmadji, 2006:177). Sedangkan menurut Kustodian Sentral Efek Indonesia (KSEI) memberikan definisi tentang corporate action yaitu,"setiap tindakan perusahaan terdaftar yang memberikan hak kepada seluruh pemilik manfaat atas efek dari jenis dan kelas yang sama seperti hak untuk memperoleh dividentunai, dividensaham, bunga, saham bonus, penawaran umum terbatas, warran atau hak-hak lainnya."

Dividen merupakan sebagian atau seluruh laba perusahaan dalam menjalankan bisnis yang dibagikan kepada pemegang saham (Tandelilin, 2010:32). Investor mendapatkan dividen setiap periode sesuai dengan jumlah saham yang dimiliki. Menurut Halim (2007:16) "dividen merupakan pembagian keuntungan yang diberikan perusahaan penerbit saham tersebut atas keuntungan yang diperoleh perusahaan". Jika Perusahaan memutuskan untuk membagi keuntungan dalam dividenmaka semua pemegang saham biasa mendapatkan hak yang sama. Pembagian dividenuntuk saham biasa dapat dilakukan jika perusahaan sudah membayar dividenuntuk pemegang saham preferen. Menurut Gitman

(2009) dividentunai (cash dividend) adalaah dividen yang dibayarkan dalam bentuk 
Yusrina, et al/Jurnal Ekonomi Syariah Teori dan Terapan Vol. 6 No. 12 Desember 2019: 2512-2526;

ANALISIS PERBEDAAAN AVERAGE ABNORMAL RETURN DAN TRADING VOLUME ACTIVITY SEBELUM DAN SESUDAH PERISTIWA DIVIDEN TUNAI PADA PERUSAHAAN YANG TERDAFTAR DI JAKARTA ISLAMIC INDEX (JII) PERIODE 2014 - 2017

tunai / kontan, dividenini pada umumnya dibagikan secara berkala seperti tahunan atau stiap enam bulan sekali. Tujuan perusahaan membagikan dividen kas kepada pemegang saham adalah untuk memaksimalkan nilai pemegang saham dan pemegang saham akan menilai dividenini sebagai pengembalian investasi atas modal yang telah ditanamkan pada perusahaan.

Pengumuman emiten atas dividen yang akan dibayarkan kepada pemegang saham yang disebut juga dengan tanggal pengumuman dividen. Rincian tanggal yang diperhatikan dalam pembayaran dividenadalah sebagai berikut (Sinuraya, 1999):

a. Tanggal pengumuman (declaration date)

Tanggal pengumuman merupakan tanggal yang mana secara resmi diumumkan oleh emiten tentang bentuk dan besarnya serta jadwal pembayaran dividenyang akan dilakukan. Pengumuman ini biasanya untuk pembagian dividenregular. Isi pengumuman tersebut menyampaikan hal-hal yang dianggap penting yakni: tanggal pencatatan, tanggal pembayaran, besarnya dividenkas per lembar.

b. Tanggal pencatatan (date of record) Tanggal ini perusahaan melakukan pencatatan nama-nama pemegang saham. Para pemilik saham yang terdaftar pada daftar pemegang saham tersebut diberikan hak, sedangkan pemegang saham yang tidak terdaftar pada tanggal pencatatan tidak diberikan hak untuk memperoleh dividen.

c. Tanggal cum-dividend

Tanggal ini merupakan tanggal hari terakhir perdagangan saham yang masih melekat hak untuk mendapatkan dividenbaik dividentunai maupun dividensaham.

d. Tanggal ex-dividend

Tanggal perdagangan saham tersebut sudah tidak melekat lagi hak untuk memperoleh dividen. Jadi jika investor membeli saham pada tanggal ini atau sesudahnya, maka investor tersebut tidak dapat mendaftarkan namanya untuk mendapatkan dividen.

e. Tanggal pembayaran (payment date) Tanggal ini merupakan saat pembayaran dividenoleh perusahaan kepada para pemegang saham yang telah mempunyai hak atas dividen. Jadi pada tanggal tersebut, para investor sudah dapat mengambil dividensesuai dengan bentuk dividenyang telah diumumkan oleh emiten (dividentunai, dividensaham).

Untuk memudahkan investor untuk mengamati perkembangan saham syariah, diperlukan tolak ukur yang berkompeten untuk dijadikan dasar perhitungan dan pengamatan keadaan saham syariah. Sehingga terciptalah indeks saham khusus saham syariah yaitu Jakarta Islamic Index (JII). Di Indonesia prinsip-prinsip penyertaan modal secara 
Yusrina, et al/Jurnal Ekonomi Syariah Teori dan Terapan Vol. 6 No. 12 Desember 2019: 2512-2526;

ANALISIS PERBEDAAAN AVERAGE ABNORMAL RETURN DAN TRADING VOLUME ACTIVITY SEBELUM DAN SESUDAH PERISTIWA DIVIDEN TUNAI PADA PERUSAHAAN YANG TERDAFTAR DI JAKARTA ISLAMIC INDEX (JII) PERIODE 2014 - 2017

syariah tidak diwujudkan dalam bentuk saham syariah ataupun non-syariah, melainkan berupa pembentukan indeks yang memenuhi prinsip-prinsip syariah. untuk lebih amannya, saham yang delisting dalam Jakarta Islamic Index (JII) merupakan saham-saham yang sesuai syariah. Dikatakan demikian, karena emiten yang terdaftar dalam Jakarta Islamic Indexakan selalumengalami proses penyaringan berdasarkan kriteria yang telah ditetapkan.(sumber.id.wikipedia.org)

\section{Penelitian Terdahulu}

Yuni Rahmawati (2009) melakukan penelitian tentang "Analisis perbedaan abnormal return dan volume perdagangan saham sebelum dan sesudah tanggal pengumuman deviden tunai (Study pada perusahaan di Jakarta Islam Index)" dengan menggunakan uji normalitas, uji T. variabel yang digunakan adalah abnormal return dan trading volume activity sebagai variabel dependen. hasil dari penelitian tersebutmenunjukkan bahwa terdapat perbedaan yang signifikan antara abnormal return sebelum dan sesudah pengumuman deviden, tidak ada perbedaan yang signifikan antara volume perdagangan saham sebelum dan sesudah pengumuman deviden.

Dika ayu (2013) melakukan penelitian tentang "Pengaruh reaksi pasar terhadap pengumuman deviden pada perusahaan manufaktur" dengan menggunakan uji One Sample t-test dan Paired Sample t-test. Variabel yang digunakan adalah Abnormal Return dan Trading Volume Activity sebagai variabel dependen. hasil penelitian ini menunjukkan signifikan yang berarti bahwa ada reaksi pasar terhadap perubahan harga saham dan volume perdagangan, tetapi, bukan untuk abnormal return yang ditunjukkan tidak ada hasil yang signifikan. Ini berarti bahwa pengumuman deviden umumnya diasumsikan berita buruk yang tidak mempengaruhi pengembalian abnormal.

Sofiani, yulan sari (2013) melakukan penelitian tentang "Pengaruh pengumuman deviden terhadap reaksi pasar modal pada perusahaan manufaktur yang terdaftar di Bursa Efek Indonesia" dengan menggunakan uji paired sample t test dan uji beda wilcoxon signed rank test. Variabel yang digunakan adalah Abnormal Return dan Trading Volume Activity sebagai variabel dependen. hasil uji paired sample $\dagger+$ test dan uji beda wilcoxon sign rank test menunjukan bahwa tidak terdapat perbedaan abnormal return dan trading volume activity yang signifikan sebelum dan sesudah peristiwa, yang berarti pasar modal tidak berekasi terhadap pengumuman deviden. Peristiwa pengumuman deviden tidak mengandung muatan informasi bagi investor.

Heriyati chrisana (2016) melakukan penelitian tentang "Analisis raeksi pasar sebelum dan sesudah pengumuman deviden tunai pada perusahaan property 
Yusrina, et al/Jurnal Ekonomi Syariah Teori dan Terapan Vol. 6 No. 12 Desember 2019: 2512-2526;

ANALISIS PERBEDAAAN AVERAGE ABNORMAL RETURN DAN TRADING VOLUME ACTIVITY SEBELUM DAN SESUDAH PERISTIWA DIVIDEN TUNAI PADA PERUSAHAAN YANG TERDAFTAR DI JAKARTA ISLAMIC INDEX (JII) PERIODE 2014 - 2017

dan real estate di Bursa Efek Idonesia" dengan menggunakan uji Paired Sample T Test. Variabel yang digunakan adalah Abnormal Return dan Trading Volume Activitysebagai variabel dependen. Hasil dari penelitian tersebut menunjukkan bahwa tidak Perbedaan Aktivitas Volume Perdagangan (TVA) dan Pengembalian abnormal sebelum dan setelah deviden pengumuman.

\section{METODE PENELITIAN}

\section{Pendekatan Penelitian}

Penelitian ini menggunakan jenis penelitian kuantitatif, dengan metode event study.Tujuan dari penelitian kuantitatif adalah menemukan hubungan antar variabel yang diuji, menguji teori dan mencari generalisasi yang mempunyai nilai prediktif (sugiyono, 2014:14) Peristiwa yang diamati adalah peristiwa pengumuman cash dividend dengan melihat reaksi yang terjadi di pasar dengan menggunakan tolak ukur trading volume dan activity abnormal return

Periode pengamatan levent window) dalam penelitian ini dilaukan selama 80 hari perdagangan dibursa yang terdiri dari periode estimasi selama 60 hari dan periode pengamatan 20 hari. dengan tujuan untuk mengamati harga saham 10 hari (t-10) sebelum terjadinya cash dividend, $t=0$ saat terjadinya cash dividend, dan 10 hari $(t+10)$ setelah terjadinya cash dividend. Serta periode estimasi selama 60 hari. dan diolah menggunakan aplikasi STATA 14.

\section{Identifikasi Variabel}

Variabel merupakan sebuah objek yang akan diamati oleh peneliti untuk dianalisis dan ditarik kesimpulan dari hasil yang diperoleh dalam analisis tersebutatas sebuah permasalahan (peristiwa yang diteliti). Adapun variabelvariabel yang digunakan dalam penelitian ini adalah sebagai berikut :

1. Peristiwa atau event. Peristiwa pada penilitian ini yaitucash dividend

2. Average Abnormal Return (AAR)

3. Trading Volume Activity (TVA)

\section{Definisi Operasional}

Tujuan pemberian definisi operasional yaitu untuk mengantisipasi kesalahpahaman makna dan penafsiran ganda atas variabel-variabe yang diteliti. Adapun definisi atas variabel variabel yang digunakan padapenelitian ini yaitu :

1. cash dividend

Peristiwa cash dividendmerupakan objekpada penelitian event study. .variabel ini merupakan acuan pegukuran variabel lainya dimana setiap tanggal pengumuman dividen yang di jadikan $\mathrm{t}-0$. Dividenini pada umumnya dibagikan secara berkala seperti tahunan atau stiap enam bulan sekali yang dilakukan olehperusahaan-perusahaan publik yang terdaftar di Jakarta Islamic Index (JII) periode 2014 - 2017.

2. Average Abnormal Return (AAR)

Average Abnormal Return (AAR) merupakan selisih dari rata-rata 
Yusrina, et al/Jurnal Ekonomi Syariah Teori dan Terapan Vol. 6 No. 12 Desember 2019: 2512-2526;

ANALISIS PERBEDAAAN AVERAGE ABNORMAL RETURN DAN TRADING VOLUME ACTIVITY SEBELUM DAN SESUDAH PERISTIWA DIVIDEN TUNAI PADA PERUSAHAAN YANG TERDAFTAR DI JAKARTA ISLAMIC INDEX (JII) PERIODE 2014 - 2017

pendapatan rill saham dikurangi dengan pendapatan pasar saham.

3. Trading Volume Activity (TVA)

$$
\text { Trading Volume Activity (TVA) }
$$

merupakan penjualan dari setiaptransaksi yang terjadi di bursa saham pada waktu atau periode tertentu danpada jenis saham

\section{Jenis Dan Sumber Data}

$$
\text { Data sekunder yang }
$$

dipakaiadalah data harga dan volume perdagangan saham yang tercatat di Jakarta Islamic Index (JII) yang melakukan aksi korporasi berupa cash dividendpada periode 2014 - 2016 yang diakses melalui (www.duniainvestasi.com), serta berbagaisumber lainnya yang bersifat relevan dengan penelitian ini baik dari buku, jurnalpenelitian maupun skripsi terdahulu.Data yang digunakan dalam penelitian ini sebagai berikut :

1. Tanggal pengumuman cash dividend pada emiten yang terdaftar di Jakarta Islamic Index (JII).

2. Closing price atau harga penutupan saham harian pada masing-masing saham selama periode penelitian.

3. Volume perdagangan harian pada masing-masing saham selamaperiode penelitian.

\section{Populasi dan Sampel}

Penelitian ini bertujuan untuk meneliti pengaruh dari pengumuman cash dividendterhadap volume perdagangan dan return saham sehingga sampel daripenelitian ini masuk ke dalam jenis purposive sampling. Sugiyono
(2012:85) mengatakan bahwa purposive sampling adalah teknik penentuan sampel dengan pertimbangan tertentu. Berikut merupakan kriteria sampel yangdigunakan sebagai data :

1. Emiten yang terdaftar pada Jakarta Islamic index periode 2014-2017 pada saat melakukan aksi korporasi cash dividend

2. Perusahaan yang masuk dalam kriteria penelitian tidak melakukan aksi korporasi selain cash dividendpada periode pengamatan.

3. Saham perusahaan sampel adalah saham yang aktif diperdagangkan di pasar saham untuk mengetahui seberapa besar pengaruh cash dividend terhadap Average Abnormal Return dan Trading Volume Activity.

Tabel 1.

Proses Penentuan Kriteria Sampel (Purposive Sampling)

\begin{tabular}{|l|c|}
\hline \multicolumn{1}{|c|}{ Kriteria Sampel } & $\begin{array}{c}\text { Jumlah } \\
\text { Sampel }\end{array}$ \\
\hline Emiten Jakarta Islamic Index & 30 \\
\hline $\begin{array}{l}\text { Emiten melakukan peristiwa } \\
\text { cash dividen }\end{array}$ & 17 \\
\hline $\begin{array}{l}\text { Jumlah pengamatan } \\
\text { sampel selama 2014-2016 }\end{array}$ & 91 \\
\hline
\end{tabular}

\section{Tekhnik Analisis}

Teknik analisis yang digunakan dalam penelitian ini adalah satatistik parametik dengan membandingkan rata rata abnormal return (AAR) dan rata rata trading volume activity (TVA), sebelum dan sesudah peristiwa pengumuman cash dividend.

Periode pengamatan dilakukan selama 80 hari perdagangan dibursa yang terdiri dari periode estimasi selama 
Yusrina, et al/Jurnal Ekonomi Syariah Teori dan Terapan Vol. 6 No. 12 Desember 2019: 2512-2526;

ANALISIS PERBEDAAAN AVERAGE ABNORMAL RETURN DAN TRADING VOLUME ACTIVITY SEBELUM DAN SESUDAH PERISTIWA DIVIDEN TUNAI PADA PERUSAHAAN YANG TERDAFTAR DI JAKARTA ISLAMIC INDEX (JII) PERIODE 2014 - 2017

60 hari dan periode pengamatan 20 hari. dengan tujuan untuk mengamati harga saham 10 hari (t-10) sebelum terjadinya cash dividend, $t=0$ saat terjadinya cash dividend, dan 10 hari $(t+10)$ setelah terjadinya cash dividend. Serta periode estimasi selama 60 hari

sampel penelitian selama periode pengamatan

pada periode sebelum pengumuman cash dividend nilai minimum Abnormal return saham sebesar $-0,021641011$, nilai maksimum sebesar 0,076022855 . Nilai mean (rata-rata)

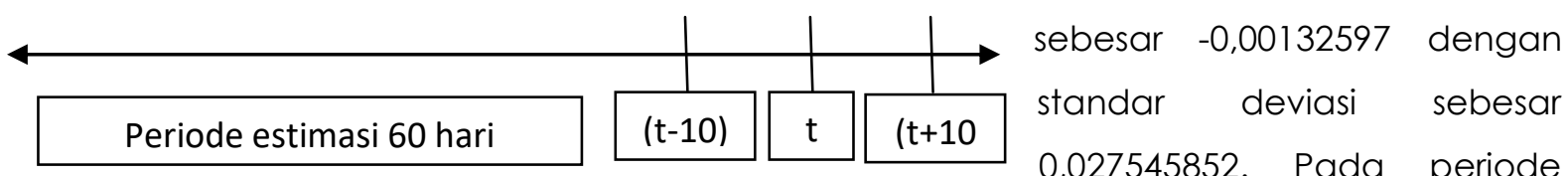

Gambar 1. Periode Uji

Melakukan uji hipotesis dengan aplikasi STATA ver. 14. Dari hasil uji kenormalan data, maka uji hipotesis yang didapat AAR tidak berdistribusi normal, maka tekhnik uji beda duasampel berpasangan yang digunakan adalah Uji PeringkatWilcoxon (Wilcoxon Signed Rank Test) yang merupakan ujistatistik non parametrik. TVA terdistribusi normal, maka tekhnik uji beda dua sampel berpasangan yang digunakan adalah paired Sample tTest yangmerupakan uji statistik parametrik. Menentukan level of significance yaitu sebesar $5 \%$

\section{HASIL DAN PEMBAHASAN}

\section{Statistik Deskriptif Average Abnormal Return}

Statistik deskriptif memberikan gambaran umum dari variabel penelitian Abnormal return. Analisis yang digunakan adalah nilai rata-rata (mean), nilai minimum dan maksimum serta standar deviasi. Tabel berikut merupakan hasil statistik deskriptif dari Abnormal return pada seluruh emiten yang menjadi setelah pengumuman cash dividen nilai minimum Abnormal return saham sebesar -0,021598932, nilai maksimum sebesar 0,022261542 . Nilai mean (rata-rata) sebesar -0,008966292 dengan standar deviasi sebesar 0,011263641.

Tabel 2.

Average Abnormal Return (AAR) Harian

\begin{tabular}{|c|c|c|c|}
\hline \multicolumn{2}{|c|}{ Sebelum } & \multicolumn{2}{|c|}{ Sesudah } \\
\hline $\begin{array}{c}\text { UJl } \\
\text { period } \\
e\end{array}$ & TVA & $\begin{array}{c}\text { Uji } \\
\text { period } \\
e\end{array}$ & TVA \\
\hline$t-10$ & $\begin{array}{c}- \\
0,00936326 \\
6\end{array}$ & †0 & $\begin{array}{c}0,02226154 \\
2\end{array}$ \\
\hline t-9 & $\begin{array}{c}- \\
0,00754786 \\
3\end{array}$ & $t+1$ & $\begin{array}{c}- \\
0,02159893 \\
2\end{array}$ \\
\hline$t-8$ & $\begin{array}{c}- \\
0,01230563 \\
2\end{array}$ & $t+2$ & $\begin{array}{c}- \\
0,01431721 \\
7\end{array}$ \\
\hline$t-7$ & $\begin{array}{c}- \\
0,00631078\end{array}$ & $t+3$ & $\begin{array}{c}- \\
0,01505372 \\
1\end{array}$ \\
\hline$t-6$ & $\begin{array}{c}- \\
0,00883905 \\
4\end{array}$ & $t+4$ & 0,01169575 \\
\hline$t-5$ & $\begin{array}{c}- \\
0,00736149\end{array}$ & $t+5$ & $\begin{array}{c}- \\
0,01337618 \\
9\end{array}$ \\
\hline$t-4$ & $\begin{array}{c}- \\
0,00655943 \\
6\end{array}$ & $t+6$ & $\begin{array}{c}- \\
0,00722262\end{array}$ \\
\hline$t-3$ & $\begin{array}{c}- \\
0,00935402 \\
3\end{array}$ & $t+7$ & $\begin{array}{c}- \\
0,00752450 \\
7\end{array}$ \\
\hline
\end{tabular}


Yusrina, et al/Jurnal Ekonomi Syariah Teori dan Terapan Vol. 6 No. 12 Desember 2019: 2512-2526;

ANALISIS PERBEDAAAN AVERAGE ABNORMAL RETURN DAN TRADING VOLUME ACTIVITY SEBELUM DAN SESUDAH PERISTIWA DIVIDEN TUNAI PADA PERUSAHAAN YANG TERDAFTAR DI JAKARTA ISLAMIC INDEX (JII) PERIODE 2014 - 2017

\begin{tabular}{|c|c|c|c|}
\hline$t-2$ & $\begin{array}{c}0,02164101 \\
1\end{array}$ & $t+8$ & $-0,0145713$ \\
\hline$t-1$ & $\begin{array}{c}0,07602285 \\
5\end{array}$ & $t+9$ & $\begin{array}{c}0,00678331 \\
9\end{array}$ \\
\hline & & $t+10$ & $\begin{array}{c}0,00874719 \\
6\end{array}$ \\
\hline \multicolumn{4}{|c|}{ Terlihat penurunan average }
\end{tabular}

abnormal return yang paling besar terjadi pada t-2 dengan nilai average abnormal return sebesar $-0,021641011$, sedangkan kenaikan abnormal return terjadi cukup besar pada t-1 dengan nilai average abnormal return sebesar 0,076022855, hal tersebut menunjukkan bahwa kedua reaksi pasar yang dominan terjadi sebelum pengumuman cash dividend.

\section{Uji Normalitas Pada Average Abnormal}

\section{Return}

Dari hasil uji Shapiro-Wilk normality test yang telah dilakkan dapat disimpulkan bahwa variabel Average Abnormal Returntidak terdistribusi secara normal, dengan probabilitas kesalahan pada periode yaitu sebesar 0.00000 , dibawah dari tingkat signifikansi 0,05.Dari hasil data tersebut maka dapat disimpulkan bahwa Average Abnormal Returntidak terdistribusi secara normal, dan akan dilanjutkan dengan uji peringkat Wilcoxon (Wilcoxon Signed Rank Test).

\section{Analsisis Average Abnormal Return dengan Wilcoxon Signed Rank Test}

Uji wilcoxon digunakan karena pada hasil dari uji normalitas pada AAR dinyatakan tidak normal, sehingga uji sample paired t-test tidak dapat digunakan.maka akan dilakukanuji peringkat Wilcoxon (Wilcoxon Signed Rank Test).

hasil berikut merupakan hasil uji Wilcoxon signed rank test pada Average Abnormal Return dengan menggunakan aplikasi stata ver. 14.

unadjusted variance $\quad 827.75$

adjustment for ties $\quad 0.00$

adjustment for zeros $\quad 0.00$

adjusted variance $\quad 827.75$

Ho: aar $\quad=0$

$$
z=-2.589
$$

Prob $>|z|=0.0096$

Dari hasil uji diatas menunjukkan bahwa probabilitas nilai $z$ sebesar 0.0096 atau kurang dari 0,05 , yang artinya bahwaHO 2 ditolak H1 2 diterima. sehingga dapat disimpulkan bahwa terdapat perbedaan yang signifikan atas average abnormal return (AAR) sebelum dan sesudah pengumuman.

\section{Statistik Deskriptif Trading Volume Activity}

Pada bagian ini akan dijelaskan mengenai hasil pengolahan data Trading Volume Activity (TVA) selama periode pengamatan yakni 10 hari sebelum pengumuman cash dividend serta 10 hari saat dan setelah pengumuman cash dividend. Metode perolehan nilai Trading Volume Activity (TVA) menggunakan prosentase jumlah saham yang di perdagangkan pada periode $\dagger$ terhadap jumlah saham yang beredar (tradable share). 
Yusrina, et al/Jurnal Ekonomi Syariah Teori dan Terapan Vol. 6 No. 12 Desember 2019: 2512-2526;

ANALISIS PERBEDAAAN AVERAGE ABNORMAL RETURN DAN TRADING VOLUME ACTIVITY SEBELUM DAN SESUDAH PERISTIWA DIVIDEN TUNAI PADA PERUSAHAAN YANG TERDAFTAR DI JAKARTA ISLAMIC INDEX (JII) PERIODE 2014 - 2017

pada periode sebelum pengumuman cash dividend, nilai minimum volume perdagangan saham sebesar 0,0011279, nilai maksimum sebesar 0,0015482 . Nilai mean (rata-rata) sebesar 0,0013141 dengan standar deviasi sebesar 0,0001195 . Nilai mean menunjukkan bahwa rata-rata transaksi saham yang di perdagangkan sebelum periode pengumuman cash dividen yaitu sebesar 0,0013141 .

$$
\text { Pada periode sesudah }
$$
pengumuman cash dividend, nilai minimum volume perdagangan saham sebesar 0,0012805, nilai maksimum sebesar 0,0017809 . Nilai mean (rata-rata) sebesar 0,0014259 dengan standar deviasi sebesar 0,000145202 . Nilai mean menunjukkan bahwa rata-rata transaksi saham yang di perdagangkan sesudah periode pengumuman cash dividend yaitu sebesar 0,0014259.

Tabel 3.

Trading Volume Activity (TVA) Harian

\begin{tabular}{|c|c|c|c|}
\hline \multicolumn{2}{|c|}{ Sebelum } & \multicolumn{2}{c|}{ Sesudah } \\
\hline $\begin{array}{c}\text { UJI } \\
\text { periode }\end{array}$ & TVA & $\begin{array}{c}\text { Uji } \\
\text { periode }\end{array}$ & TVA \\
\hline$t-10$ & 0,0015482 & $t 0$ & 0,0015685 \\
\hline$t-9$ & 0,0013157 & $t+1$ & 0,0017809 \\
\hline$t-8$ & 0,0013669 & $t+2$ & 0,0014465 \\
\hline$t-7$ & 0,0011465 & $t+3$ & 0,0013139 \\
\hline$t-6$ & 0,0011279 & $t+4$ & 0,0014400 \\
\hline$t-5$ & 0,0013331 & $t+5$ & 0,0013638 \\
\hline$t-4$ & 0,0013158 & $t+6$ & 0,0014556 \\
\hline$t-3$ & 0,0013145 & $t+7$ & 0,0014052 \\
\hline$t-2$ & 0,0012778 & $t+8$ & 0,0013006 \\
\hline$t-1$ & 0,0013945 & $t+9$ & 0,0012805 \\
\hline & & $t+10$ & 0,0013297 \\
\hline
\end{tabular}

Data diatas menunjukkan bahwa nilai volume minimum perdagangan saham sebelum adanya pengumuman
Cash dividend terjadi pada $t-6$ dengan nilai rata-rata TVA oleh seluruh emiten sebesar 0,0011279, sedangkan nilai maksimum sebelum adanya pengumuman cash dividend terjadi pada t-10 dengan nilai rata-rata TVA olehseluruh emiten sebesar 0,0015482. Pada saat sesudah pengumuman cash dividend nilai minimum terjadi pada ++9 dengan nilai rata-rata TVA oleh seluruh emiten sebesar 0,0012805, dan peningkatan nilai direspon oleh investor pada periode $t+1$ dengan nilai TVA sebesar 0,0017809

\section{Uji Normalitas Pada Trading Volume}

\section{Activity}

Dari hasil uji Shapiro-Wilk normality test yang telah dilakukan dapat menunjukkan bahwa data terdistribusi secara normal dengan tingkat probabilitas sebesar 0.07229 atau lebih dari 0,05 . Dari hasil data tersebut maka dapat disimpulkan bahwa Trading Volume Activity terdistribusi secara normal, dan akan dilanjutkan dengan uji paired t-test.

\section{Analisis Trading Volume Activity dengan Uji Paired T Test}

Uji paired t-test digunakan karena pada hasil dari uji normalitas pada TVA dinyatakan data terdistribusi secara normal, sehingga uji sample paired t-test dapat digunakan.

Hasil berikut merupakan hasil uji pada Trading Volume Activityd engan menggunakan aplikasi stata ver. 14.

$$
\begin{aligned}
& \text { Mean(diff) }=\text { mean(TVA Setelah }- \text { TVA } \\
& \text { Sebelum ) } t=2.3476
\end{aligned}
$$


Yusrina, et al/Jurnal Ekonomi Syariah Teori dan Terapan Vol. 6 No. 12 Desember 2019: 2512-2526;

ANALISIS PERBEDAAAN AVERAGE ABNORMAL RETURN DAN TRADING VOLUME ACTIVITY SEBELUM DAN SESUDAH PERISTIWA DIVIDEN TUNAI PADA PERUSAHAAN YANG TERDAFTAR DI JAKARTA ISLAMIC INDEX (JII) PERIODE 2014 - 2017

Ho: mean(diff) $=0$ degrees of freedom $=9$

Ha: mean(diff) < $0 \quad$ Ha: mean(diff) != 0

Ha: mean(diff) $>0$

$\operatorname{Pr}(\mathrm{T}<\dagger)=0.9783 \quad \operatorname{Pr}(|\mathrm{T}|>|\dagger|)=0.0435$

$\operatorname{Pr}(\mathrm{T}>\dagger)=0.0217$

Dari hasil perhitungan data diatas menunjukkan bahwa nilai probabilitas $\operatorname{Pr}(\mathrm{T}<\mathrm{t})<0$ yaitu sebesar 0.9783 dan nilai probababilitas $\operatorname{Pr}(\mathrm{T}>t)>0$ yaitu sebesar 0.0217, maka dapat disimpulkan bahwa nilai probabilitas hitung dari keduanya lebih dari 0,05 yang menunjukkan bahwa $\mathrm{HO} 1$ diterima atau $\mathrm{Hl}$ lditolak. Artinya, tidak terdapat perbedaan trading volume activity sebelum dan sesudah pengumuman.

Hasil dan Pembahasan Average Abnormal Return Sebelum dan Sesudah

Pengumuman

Hasil pernyataan tersebut diperoleh berdasarkan pengamatan penelitianyang dapat dilihat pada tabel 2 dan gambar 2. Berikut merupakan grafik Average Abnormal Return pada pengamatan harian

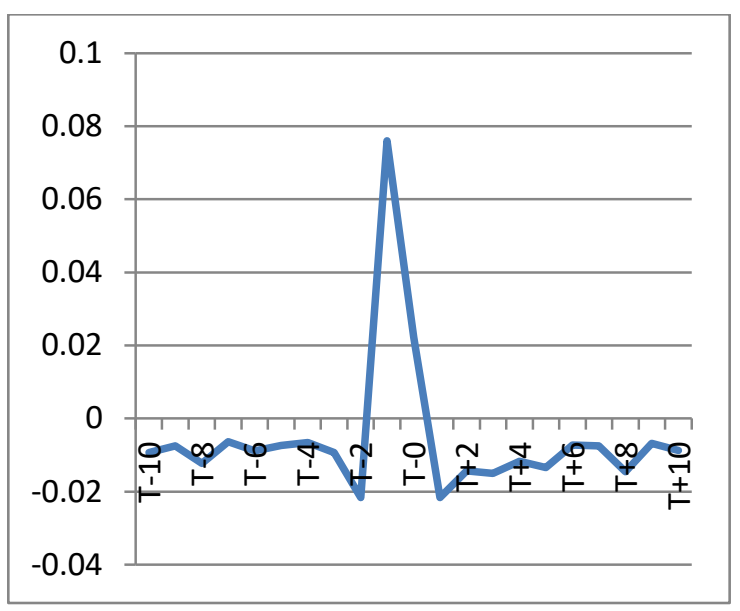

Gambar 2.

Grafik Average Abnormal Return
Pada grafik diatas mennjukan bahwa rata - rata abnormal return cenderung stabil ditandai dengan pada †10 sampai dengan $t-3$, dan mengalami kenaikan secara drastis pada t-2 hingga mencapai puncaknya pada t-1 lalu mengalami penurunan hingga $t+1$. dan kembali stabil sesudah pengumuman cash dividen, meskipun pada saat sebelum pengumuman mengalami kenaikan yang sangat drastis.

Terdapatnya nilai rata - rata average abnormal return pada seputaran tanggal peristiwa cumdate mengindikasikan bahwa dividen diminati oleh investor dikarenakan pemberian dividen tunai dapat mengurangi ketidakpastian investor. Serta dapat membagikan laba kepada pemegang saham dari besaran laba yang diperoleh susai dengan kepemilikan saham.

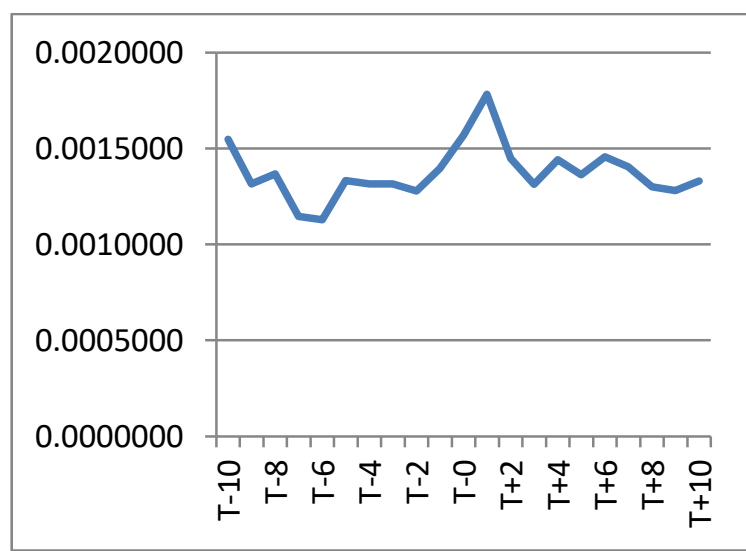

Gambar 3.

Hasil dan Pembahasan Trading Volume Activity Sebelum dan Sesudah Pengumuman

Dari grafik data diatas menunjukkan bahwa terdapat perubahan rata-rata volume perdagangan saham 
Yusrina, et al/Jurnal Ekonomi Syariah Teori dan Terapan Vol. 6 No. 12 Desember 2019: 2512-2526;

ANALISIS PERBEDAAAN AVERAGE ABNORMAL RETURN DAN TRADING VOLUME ACTIVITY SEBELUM DAN SESUDAH PERISTIWA DIVIDEN TUNAI PADA PERUSAHAAN YANG TERDAFTAR DI JAKARTA ISLAMIC INDEX (JII) PERIODE 2014 - 2017

antara sebelum dan sesudah pengumuman dengan nilai rata rata mulai mengalami kenaikan yaitu pada t-2 hingga $t+1$ pengumuman. namun pada †+2 sampai dengan $\dagger+10$ tidak terjadi perbedaan TVA yang signifikan. Nilai ratarata volume perdagangan saham tertinggi terjadi ketika periode satu hari setelah pengumuman, hal ini menunjukkan bahwa pasar mereaksi pengumuman cash dividen dengan terdapatnya volume perdagangan yang besar pada seputaran tanggal peristiwa, sehingga dapat disimpulkan bahwa pada grafik terjadi perubahan pasar yang tidak signifikan atas cash dividen yang ditandai dengan meningkatnya volume perdagangan.

\section{SIMPULAN}

Berdasarkan hasil analisis dan pembahasan, maka penelitian reaksi pasaratas pengumuman dividen (Studi Pada Emiten yang Terdaftar Di Jll periode 2014- 2017), dapat ditarik kesimpulan sebagai berikut :

1. Terdapat perbedaanAverage Abnormal Return sebelum dan sesudahpengumumancash

dividenpada emiten saham syariah yang terdaftar diJakarta Islamic Index (JII) periode 2014-2017.

2. Tidak terdapat perbedaan nilai ratarata Trading Volume Activity sebelum dan sesudah pengumuman cash dividenpada emiten saham syariah yangterdaftar di Jakarta Islamic Index (JII) periode 2014-2017.
Dari beberapa pengujian terhadap reaksi pasar atas pengumuman cash dividen investor merespon pengumuman cash dividen dengan terdapatnya reaksi dariperubahan rata rata abnormal return tetapi. Perbedaan penting antara pengujian harga dan volume adalah bahwa harga menentukan perubahan dalam pengharapan pasar sebagai suatu keseluruhan sedangkan volume menentukan perubahan dalam pengharapan investor secara individual. Suatu informasi pengumuman dividen ada kemungkinan tidak akan berpengaruh terhadap pasar secara utuh tetapi berpengaruh terhadap investor secara individu.

\section{DAFTAR PUSTAKA}

Ali Arifin. 2004. "Membaca Saham" Penerbit Andi: Yogyakarta.

Darmadji, Tjiptono dan Fakhruddin. 2006. Pasar Modal Di Indonesia. Edisi Kedua. Jakarta: Salemba Empat.

Darmadji, Tjiptono dan Fakhruddin. 2011. Pasar Modal Di Indonesia. Edisi Ketiga. Jakarta: Salemba Empat

Faizah. 2009. Analisis Pengumuman Dividen Terhadap Harga Saham pada JII Tahun 2006 - 2008. Jakarta. Fakultas Ekonomi dan IImu Sosial Universitas Islam Negeri Syarif Hidayatullah.

Hartono, jogiyanto. 2003. Teori portofolio dan analisis investasi. Edisi kesepuluh. Yogyakarta : BPFE 
Yusrina, et al/Jurnal Ekonomi Syariah Teori dan Terapan Vol. 6 No. 12 Desember 2019: 2512-2526;

ANALISIS PERBEDAAAN AVERAGE ABNORMAL RETURN DAN TRADING VOLUME ACTIVITY SEBELUM DAN SESUDAH PERISTIWA DIVIDEN TUNAI PADA PERUSAHAAN YANG TERDAFTAR DI JAKARTA ISLAMIC INDEX (JII) PERIODE 2014 - 2017

Haryanto, Sugeng. 2001. Reaksi Investor Terhadap Pengumuman Dividen di Bursa Efek Indonesia. Jurnal Keuangan dan Perbankan, Vol. 15, No. 2, Mei 2011.

Huda, nurul dan mustafa edwin nasution . 2008. Investasi pada pasar modal syariah. jakarta : kencana

Jogiyanto, H. M. 2009. Teori Portofolio dan Analisis Investasi. Edisi Keenam. Yogyakarta: BPFE Universitas Gajah Mada.

Pramana, k,s. Nyoman. 2017. Reaksi Pasar Terhadap Pengumuman Dividen di BEI. Jurnal Manajemen Unu, Vol. 6, No. 11,2017:6324 - 6356 .

Pratama, Billy. 2014. Analisis Perbedaan Harga Saham da Volume Perdagangan Sebelum dan Sesudah Pengumuman Dividen Pada Perusahaan Manufaktur yang Terdaftar di BEl. Bengkulu. Fakultas Ekonomi dan Bisnis Universitas Bengkulu.

Putra, Iman dan Asfan. 2013. Reaksi Pasa Terhadap Pengumuman Dividen Kas Pada Perusahaan yang Terdaftar di BEI. Jurnal Telaah \& Riset Akuntansi, Vol. 6 No. 1, Januari 2013.

Rahmawati, Yuni. 2009. Analisis Perbedaan Abnormal return danVolume Perdagangan Saham Sebelum dan Sesudah Tanggal

\begin{abstract}
Pengumuman Dividen Tunai. Yogyakarta. Fakultas Syariah Universitas Islam Negeri Sunan Kalijaga.
\end{abstract}

Ryandono, Muhamad Nafik Hadi. 2009. Bursa Efek dan Investasi Syariah. Jakarta: PT Serambi llmu Semesta.

Samsul, Mohammad. 2006. Pasar Modal dan Manajemen Portofolio. Jakarta: Erlangga.

Sugiyono. 2012. Metode Kuantitatif, Kualitatif dan R\&D. Cetakan ke-17. Bandung: Alfa Beta

Sunariyah. 2011. Pengantar pengethuan pasar modal. yogyakarta : UPP sekolah tinggi ilmu manajemen YKPN

Sutedi, A. 2011. Pasar Modal Syariah. Jakarta: Sinar Grafika

Tandelilin, Eduardus. 2001. Analisis Investasi dan Manajeme Protofolio. Yogyakarta: BPFE Fakultas Ekonomi UGM.

Wibowo, 2006. Analisis Pengaruh Pengumuman Dividen Terhadap Perubahan Harga saham (return) Sebelum dan Sesudah ex-dividend date Di Bursa Efek Jakarta (bej). Jurnal Informasi, Perpajakan, Akuntansi dan Keuangan Publik Vol. 1, no. 2, juli 200: Hal. 73 - 90.

www.idx.co.id di akses pada 18 september 2018 